\title{
Disseminated Postnatal Cytomegalovirus Infection in a Preterm Neonate: Autopsy Case Report
}

Ka-Young Kim, $\mathrm{MD}^{1}$, Ee-Kyung Kim, MD, $\mathrm{PhD}^{1}$, Sung-Hye Park, $\mathrm{MD}^{2}$, Yoo Jinie Kim, $\mathrm{MD}^{1}$, Seung-Han Shin, $\mathrm{MD}^{1}$, and Han-Suk Kim, MD ${ }^{1}$

${ }^{1}$ Division of Neonatology, Department of Pediatrics and ${ }^{2}$ Department of Pathology, Seoul National University College of Medicine, Seoul, Korea

\section{ABSTRACT}

Treatment guidelines for postnatal cytomegalovirus (pCMV) infection in preterm have not been established yet. Neutropenia, thrombocytopenia, hepatitis, colitis, and sepsis-like disease are among the clinical manifestations, which range from moderate to serious. We present a case of autopsy diagnosed as pCMV infection in a premature infant delivered at gestational age of 24 weeks and 5 days. On the 7 th and 14th days of birth, urinary CMV polymerase chain reaction samples were negative, ruling out congenital CMV infection. However, autopsy examination revealed that the patient had disseminated pCMV infection. CMV inclusion bodies were found in the majority of tissues, including the lung, liver, pancreas, breast, kidney, and adrenal gland, but not the placenta. The thymus exhibited significant cortical atrophy and T-cell immunodeficiency, possibly induced by dexamethasone treatment for bronchopulmonary dysplasia or by pCMV infection itself. If dexamethasone treatment is extended or high doses are considered, it may be beneficial to test the CMV infection status to prevent aggravation of infection. This case demonstrates that, despite the low prevalence, pCMV infection should be considered a differential diagnosis in preterm if other conditions or etiology cannot justify clinical deterioration.

Key Words: Cytomegalovirus infections; Infant, extremely low birth weight; Sepsis; Autopsy; Immunologic deficiency syndromes

\section{서론}

거대세포바이러스(cytomegalovirus)는 전 세계적으로 성인에서 혈청 양성률이 45\%-100\%이 고 $^{1}$, 우리나라에서는 가임기 여성의 약 $97 \%$ 가 보균자로 알려져 있다 ${ }^{2)}$. 더불어, 이 바이러스는 태아와 신생아에서 가장 흔한 바이러스 감염 중 하나이다. 선천성 거대세포바이러스 감염은 85\%-90\%에서 무증상이지만, 나머지에서는 감각신경성 난청, 발달 장애와 같은 장기 합병증을 유발하여 증상이 있을 경우에는 약 6개월간의 약물치료를 한달. 선천성 거대세포바이러스 감 염과 달리 주산기(perinatal) 즉, 출생 3 주 뒤의 감염은 증상이 없는 경우가 더 많다. 주산기 감염
Received: 25 January 2021

Revised: 19 March 2021

Accepted: 22 April 2021

Correspondence to: Ee-Kyung Kim, $\mathrm{MD}, \mathrm{PhD}$

Department of Pediatrics, Seoul National University College of Medicine, 101 Daehak-ro, Jongno-gu, Seoul 03080, Korea

Tel: +82-2-2072-3628

Fax: +82-2-743-3455

E-mail:kimek@snu.ac.kr

Copyright(c)

By Korean Society of Neonatology.

All right reserved.

This is an Open-Access article distributed under the terms of the Creative Commons At tribution Non-Commercial License (http:// creativecommons.org/licenses/by-nc/4.0), which permits unrestricted non-commercial use, distribution, and reproduction in any medium, provided the original work is pro perly cited. 
은 만삭아에 비해 미숙아에서는 증상을 나타내는 경우가 많지만), 심한 패혈증과 같은 증상(sepsis-like illness)이나 다발성 장기 손상 을 유발하는 경우는 드물다 ${ }^{5}$.

저자들은 서울대학교 어린이병원 신생아중환자실에 입원한 미숙 아에서 선천성 거대세포바이러스 감염의 증거가 없었고, 지속적인 호흡부전으로 치료받던 중 사망하여 이후에 부검을 통해 진단된 주 산기 거대세포바이러스 감염 증례 보고를 통해 감염 시기, 감염 경 로 및 원인에 대해 고찰하고 미숙아가 전신 상태의 악화를 보일 때 거대세포바이러스 감염을 감별 진단에 포함해야 한다는 것을 다시 상기하고자 한다.

\section{증례}

환아는 산과력 0-0-0-0인 37세 산모로부터 임신나이 24주 6일, 출 생체중 $700 \mathrm{~g}$ (41 백분위수)으로 서울대학교병원에서 응급 제왕절 개 수술을 통해 출생한 이융모막이양막 쌍둥이 중 첫째 남아이다. 산모는 특이 병력 없었고 인공수정으로 임신하여 타병원에서 정기 적인 산전 진찰을 받았으나 임신나이 22주 3 일에 질 출혈, 조기양막 파수 및 수축 발생하여 항생제와 자궁수축 억제제를 투약하던 중 임 신나이 24 주 1 일에 양수량 감소와 질 출혈 진행하여 본원으로 전원 되었다. 이후 늦은 태아의 심박동 감소 소견이 있어 응급 제왕절개 수술로 분만하게 되었다.

출생 후 심장박동수 1 분에 60 회 미만으로 흥부 압박을 1 분 정도 하였고, 아프가 점수는 1 분, 5 분 및 10 분에 각각 4 점, 5 점, 7 점이었 다. 환아는 기관 삽관 후 양압 환기 유지하면서 신생아중환자실에 입실하였다. 쌍둥이 둘째는 여아로 출생체중 $770 \mathrm{~g}$ (77 백분위수) 이었고 기관 삽관 후 양압 환기 유지하면서 신생아중환자실에 입실 하였다.

입원하여 시행한 신체 계측상 신장 $37.5 \mathrm{~cm}$ (22 백분위수), 머리 둘레 $26.8 \mathrm{~cm}$ (32 백분위수)이었고, 초기 검진에서 선천성 기형 소 견은 관찰되지 않았다.

신생아 호흡곤란증후군과 폐동맥 고혈압으로 고농도 산소와 흡 입 일산화질소 치료를 생후 첫날부터 시작하였고, 출생 직후 시행한 말초혈액배양검사에서 다제내성 대장균(extended spectrum betalactamase Escherichia coli) 감염이 확인되어 3주간 어타페템(ertapenem) 항생제 치료를 하였다. 생후 3 일째, 가슴 X선상 양 폐에 그 물결절 음영이 보여 자궁 내 염증으로 인한 비전형적 기관지폐이형 성증이 의심되었다(Figure 1). 출생 직후 시행한 위액의 ureaplasma, mycoplasma 중합효소연쇄반응(polymerase chain reaction, PCR) 검사는 음성이었으나 태반병리검사에서는 급성 융모막염이 확인되 었다(A [amnion] X CD [chorion and decidua] X U [umbilical cord] 2 C [chorionic plate] 4). 생후 6일째부터 거대세포바이러스를 검사하
지 않은 모유로 장관 영양을 시작했으나 생후 10 일째 저혈압이 발생 하고 산소 요구량이 증가하여 금식을 지속하였다. 생후 12 일째부터 저혈압에 대해 하이드로코르티손(hydrocortisone) 치료를 시작했 고 사망 직전까지 지속적으로 투약하였다. 생후 7일, 14 일 소변 검체 를 이용한 거대세포바이러스 PCR 검사는 음성이었다. 생후 17 일째, 산소 요구도가 증가하고 심장초음파에서 동맥관개존증 크기가 증 가하여 동맥관 결찰술을 시행하였다. 수술 후에도 흡입 산소분율 0.7 이상 필요하며 폐동맥 고혈압이 지속되어 생후 19 일째에 흡입 일로프 로스트(iloprost)를, 생후 20일째에는 트레프로스티닐(treprostinil) 치료를 시작하였다. 생후 21 일째 소변량이 감소하고 혈액요소질소 (blood urea nitrogen) $84 \mathrm{mg} / \mathrm{dL}$ 로 증가하여 시행한 신장초음파에 서 신장관류 감소되어 있고 대동맥과 좌측 총장골동맥에 혈전 의 심되는 소견이 있어 항응고치료(enoxaparin)를 시작하였다. 당시 혈소판 $57,000 / \mathrm{mm}^{2}$ 였고 이후로도 $100,000 / \mathrm{mm}^{2}$ 미만으로 지속되 었다. 생후 23 일째 다시 모유로 장관 영양을 시작하였다. 생후 29 일째 흡입 산소분율은 처음으로 0.5 미만까지 감소하였다. 생후 30 일부터 다시 산소 요구도 증가하기 시작하였고 아스파르테이트아 미노전달효소(aspartate aminotransferase) $87 \mathrm{IU} / \mathrm{L}$, 알라닌아미노 기전달효소(alanine aminotransferase) $138 \mathrm{IU} / \mathrm{L}$ 로 증가하였다. 겨 드랑이에서 시행한 감시배양검사(surveillance culture)에서 다제내 성 대장균이 동정 되어 상기 소견들에 대해 메로페넴(meropenem) 항생제 투약을 시작하였다. 생후 33 일째, 혈소판 $50,000 / \mathrm{mm}^{2}$ 미만 으로 백혈구가 제거되고 방사선 조사된 혈소판을 수혈하였다. 생 후 35일째, C-반응단백(C-reactive protein, CRP) $4.02 \mathrm{mg} / \mathrm{dL}$ 로 증 가하며 이전 감시배양검사에서 메티실린(methicillin) 내성 황색포 도상구균(Staphylococcus aureus) 동정 된 것을 고려하여 반코마이 신(Vancomycin) 항생제를 추가하였다. 생후 38일째 흡입 산소분

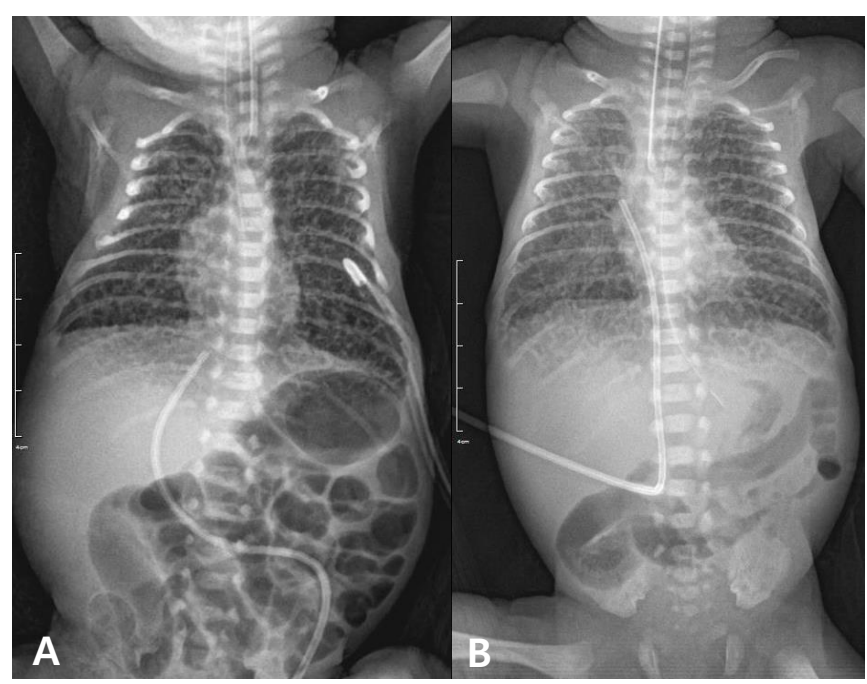

Figure 1. Chest radiographs of the twins. A chest radiograph of one of the twins (A) and the other twin (B) on the 9th day of life demonstrated reticular opacities on both lungs. 
율 0.95까지 올렸으나 맥박산소 포화도 $70 \%$ 대로 유지되어 중증 기 관지폐이형성증에 대해 생후 39일째부터 저용량 장기 덱사메타손 (dexamethasone) 치료를(D1 and D2: $0.1 \mathrm{mg} / \mathrm{kg} / \mathrm{dose}$ q12h) 시작 하였다. 생후 40 일째에는 이전에 시행한 말초혈액 및 소변배양검사 에서 동정 된 균 없고 $\mathrm{CRP} 0.50 \mathrm{mg} / \mathrm{dL}$ 로 정상화되어 항생제 치료는 중단하였으나, 흡입 산소분율은 0.95 로 유지되어 생후 41 일째부터

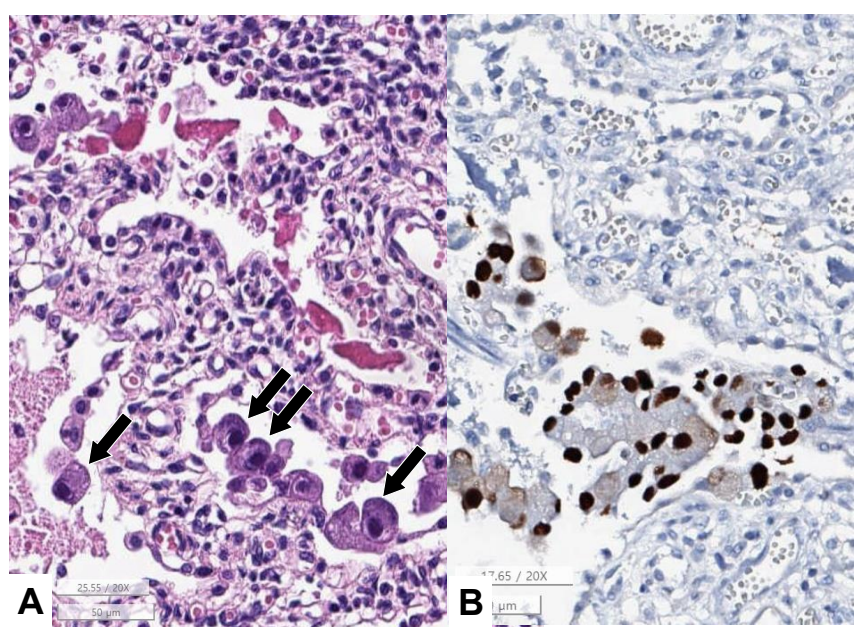

Figure 2. (A) A cytomegalic alveolar lining cell with basophilic inclusions. (B) Cytomegalovirus (CMV) immunohistochemistry reveals CMV inclusions (A: H\&E, B: CMV immunohistochemistry; cale bar $=50 \mu \mathrm{m}$ ).
저용량에서 고용량 장기 덱사메타손 치료(total $2.76 \mathrm{mg} / \mathrm{kg}$ )로 변경 하였다. 생후 53 일째, 저혈압이 발생하여 스테로이드 치료를 중단하 고 광범위 항생제(vancomycin, meropenem)를 시작하였으나 생후 56 일째 사망하였다.

생존한 쌍둥이 둘째도 유사한 임상경과를 보이고, 자궁 내 감염에 의한 폐질환 또는 유전적 간질성 폐질환의 가능성 고려하여 보호자 동의를 받고 부검을 진행하였다. 전신 부검에서 hematoxylin and eosin stain 염색상 뇌, 폐, 심장, 흥선, 위, 대장, 소장, 간, 췌장, 비장, 신장, 부신에서 거대세포바이러스 봉입체가 확인되었다(Figure 2). 흥선에서 흥선 피질의 위축 및 T-세포 결핍이 보였고 비장에서 $\mathrm{T}$-와 $\mathrm{B}$-세포 존이 관찰되지 않아서 중증복합면역 결핍증과 같은 심한 면 역 저하가 의심되었다(Figure 3). 위 검사 소견들을 바탕으로 면역결 핍 유전자 $(A D A, J A K 3, I L 2 R G)$ 검사를 시행했으나 의미 있는 변이는 검출되지 않았다.

\section{고찰}

본 증례의 환아는 생후 7 일, 14 일에 시행한 소변을 이용한 거대세 포바이러스 PCR 검사상 음성이었고 태반에서는 거대세포바이러스 봉입체가 확인되지 않았기 때문에 선천성 감염으로 보기 어렵다.

본 증례의 환아에서 생후 30 일경부터 시작된 혈소판 감소증은 혈

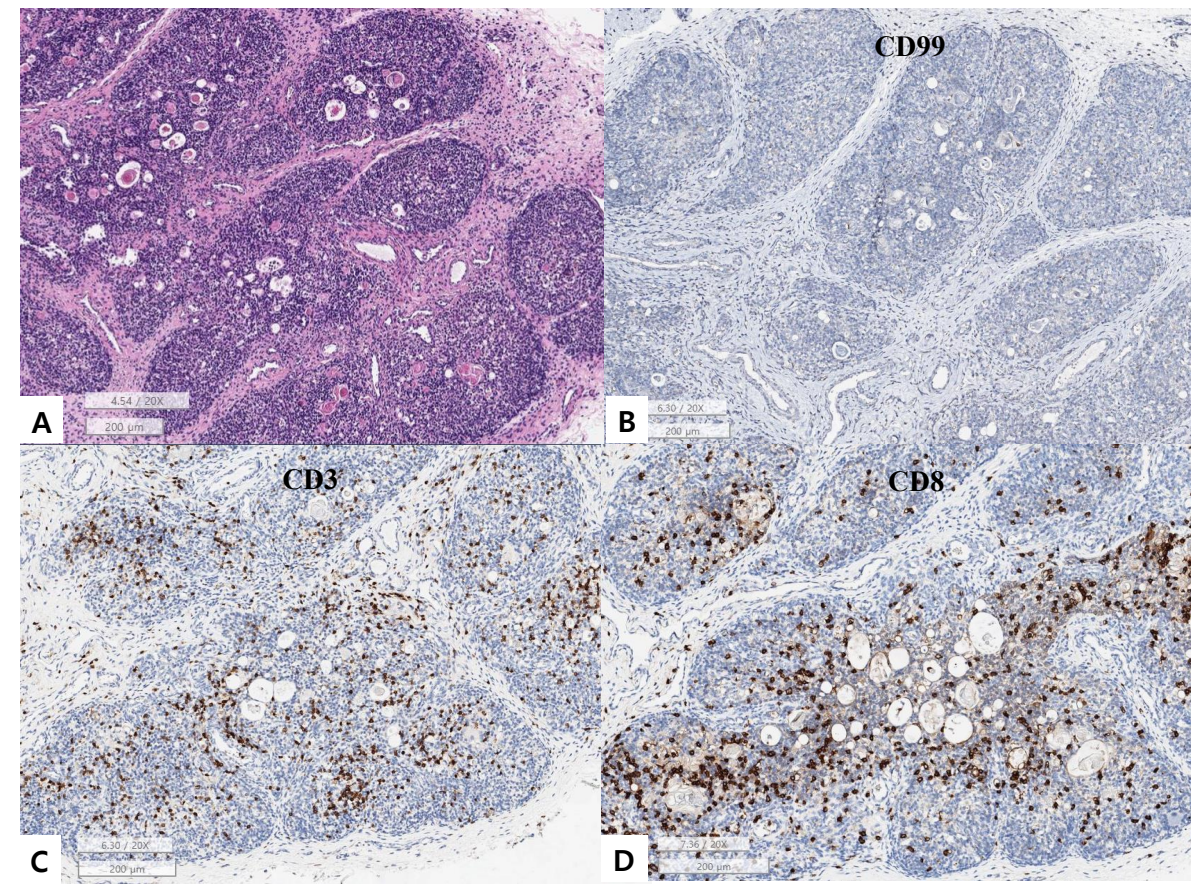

Figure 3. (A) Thymus shows cortical atrophy. (B) CD99 immunohistochemistry shows no cortical T-cell in the entire thymus. (C, D) CD3 and CD8-positive T-cells are scattered mainly in the medulla (A: H\&E, B: CD99, C: CD3, D: CD8 immunohistochemistry; scale bar $=200 \mu \mathrm{m})$. 


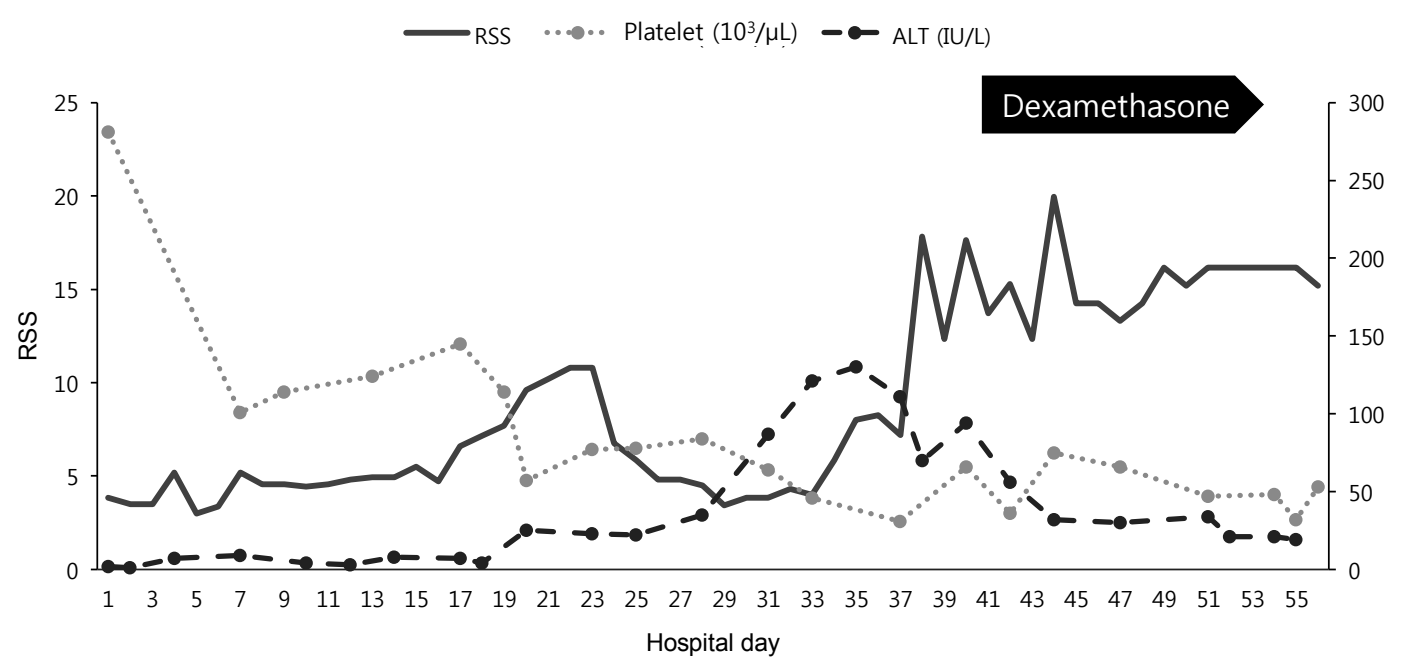

Figure 4. Changes in patient's respiratory severity score (RSS; calculated by multiplying the mean airway pressure by the fraction of inspired oxygen) of the patient. RSS significantly increased at 39 days after birth. Abbreviation: ALT, alanine aminotransferase.

전 또는 패혈증에 의한 것으로, 간 수치 상승은 장기간의 완전정맥 영양 또는 패혈증에 의한 것으로 해석하였다. 출생 직후부터 계속되 었던 호흡부전은 폐동맥 고혈압과 기관지폐이형성증에 의한 것으 로 생각하고 이에 대한 치료를 지속하였으나 증상은 일시적인 호전 후 다시 악화되었다(Figure 4). 사후 부검에서 확인된 소견과 당시의 임상증상들을 후향적으로 분석해보면, 반복되는 호흡부전과 혈소 판 감소증, 그리고 간 수치 상승은 결론적으로 거대세포바이러스 혈 증에 의한 것으로 볼 수 있다.

쌍둥이 둘째도 호흡부전이 출생 첫날부터 시작되어 생후 42 일 흡 입 산소분율 0.95 에서 맥박 산소포화도 70 대 지속되어 중증 기관지 폐이형성증 치료를 위해 저용량 덱사메타손을 투약하였다. 그러나 생후 46일째 흡입 산소분율 0.98 에도 맥박 산소포화도 70 대 유지되 어 고용량 덱사메타손 치료로 변경하였으며, 오랜 기간 인공호흡기 치료 후 회복되어 비강 캐뉼라를 통한 산소 보조 치료를 유지하면서 퇴원하였다. 반면에 쌍둥이 둘째의 경우에는 거대세포바이러스 검 사가 퇴원 시까지 지속적으로 음성이었다.

본 증례의 환아도 처음에는 기관지폐이형성증과 지속적인 폐동 맥 고혈압으로 호흡부전이 지속되었으나 거대세포바이러스에 감염 되면서 이후로 급격한 임상적 악화를 보인 것으로 생각된다. 따라서 오랜 기간 동안 높은 수준의 인공호흡기 치료가 필요하고 불안정한 심폐 상태로 위중한 경과를 보이며 치료에도 반응이 없을 경우, 세 균 및 진균 감염뿐 아니라 거대세포바이러스 감염도 함께 고려해봐 야 한다는 것을 다시 한번 본 증례를 통해 확인할 수 있었다.

출생 후 거대세포바이러스 감염되는 경로는 크게 세 가지이다. 첫 째는 출생 시 질 분비물 흡입을 통해서 감염되고, 둘째는 거대세포 바이러스가 함유된 모유를 섭취해서 감염될 수 있으며, 마지막으로 는 거대세포바이러스 혈청 양성인 혈액 수혈을 통해 감염될 수 있
다 ${ }^{6}$.

거대세포바이러스 혈청 양성인 산모의 모유는 96\%까지 거대세 포바이러스가 재활성화되며” 32 주 미만 미숙아 또는 초 저체중출생 아는 모유를 통해 최대 $20 \%$ 까지 감염된다는 보고가 있다. 모유 내 에 거대세포바이러스 DNA는 대부분 분만 2주 후에 감지되기 시작 해서 4-6주까지 증가한다 $)^{4}$. 모유를 냉동 보관하면 바이러스를 감소 시킬 수는 있으나 박멸할 수 없고, 저온 살균하면 완전히 제거할 수 있당. 본원에서는 모유를 냉동보관 한 뒤 해동하여 먹이고 저온살 균 처리는 하지 않았다. 본 증례의 환아는 생후 6 일째부터 모유를 먹 기 시작했으나 생후 10 일째 활력 징후가 불안정하여 중단했다가 생 후 3주째부터 모유를 다시 먹었고, 환아모로부터 받은 모유 $160 \mathrm{~mL}$ 와 저온살균 처리된 모유 은행의 모유 $22 \mathrm{~mL}$ 합하여 총 $182 \mathrm{~mL}$ 를 먹 었다. 환아모의 거대세포바이러스 감염 여부를 확인하지는 않았지 만 우리나라 가임기 여성의 대부분이 거대세포바이러스 보균자라 는 것을 고려할 때, 환아의 경우에도 모유를 통한 거대세포바이러 스 감염의 가능성을 배제할 수 없다. 이러한 이유로 임신나이 32 주 미만의 주수가 어리고 출생체중 $1,500 \mathrm{~g}$ 미만의 극소 저체중출생아 에서 저온살균된 모유로 수유할 것을 권장하기도 하지만 아직은 국 가에 따라서, 또는 신생아중환자실에 따라서 다양한 방식이 적용되 고 있다 ${ }^{9,10)}$.

우리나라는 거대세포바이러스 혈청 양성률이 높아서 혈액 공여 자의 거대세포바이러스 항체검사를 일괄적으로 시행하고 있지는 않다. 백혈구를 제거한 혈액의 수혈은 거대세포바이러스 혈청 음 성인 혈액의 수혈과 비교하여 거대세포바이러스에 감염될 위험이 $1 \%-2 \%$ 정도로 낮다 ${ }^{11}$. 본 증례의 환아는 생후 6 일째부터 백혈구가 제거되고 방사선 조사된 적혈구는 총 24회, 혈소판 수혈은 총 9회를 받았다. 거대세포바이러스는 세포에 연관된 바이러스(cell-associ- 
ated virus)로 주로 혈액 속 백혈구에 있어서 이를 제거할 경우 감염 을 낮춘다고 알려져 있다. 그러나 백혈구가 제거되는 정도에 따라 수혈 후 감염이 될 수 있고, 세포 외에 있는 거대세포바이러스(cellfree cytomegalovirus)의 경우에는 제거가 되지 않을 수 있다. 또한 국내 연구에 따르면 백혈구를 제거하고 방사선 처리를 한 방법이 거 대세포바이러스 감염을 유의미하게 낮추지 못했다는 결과도 있다 ${ }^{11,12)}$. 본 증례의 경우 수혈로 인한 거대세포바이러스 감염의 가능성 은 낮지만 이를 통한 감염 또한 완전히 배제할 수는 없다.

미숙아는 출생 후 거대세포바이러스에 감염되어도 중한 증상을 나타내는 경우는 드물지만 ${ }^{13)}$, 본 증례의 환아는 부검 결과 대부분의 장기에 거대세포바이러스 감염이 확인되었고 감염 부위에서 염증 반응이 없어서 중증복합면역결핍병이 의심될 정도로 심한 면역 결 핍이 있어 증상이 심하게 나타난 것으로 생각된다. 면역 결핍 상태 는 심한 기관지폐이형성증에 대해 투여한 덱사메타손 치료 또는 거 대세포바이러스 감염으로 유발되었을 가능성이 있다.

덱사메타손은 극소 저체중출생아에서 기계 환기 기간을 줄이고 발관을 하기 위해 사용되고 있으나, 덱사메타손을 투약한 환아에 서 투약하지 않은 환아에서보다 패혈증이 증가하는 것으로 보고되 고 있다 ${ }^{14)}$. 외부에서 당질 코르티코이드(glucocorticoid)를 주입하 면 흥선 세포 피질에서 세포 자살이 더 활발히 일어나게 되어 흥선 의 위축을 유발할 수 있다 ${ }^{15)}$. 본 증례의 환아는 부검 결과 흥선 피질 이 위축되어 있었는데 이는 덱사메타손에 의해 유발되었을 가능성 이 높으며, 세포 면역이 저하되어 있는 상태여서 바이러스 감염에 더 취약했을 수 있다. 또한 거대세포바이러스 감염 자체가 바이러 스를 인식하고 이에 대해 반응하는 중요한 CD8+ 림프구를 손상시 킬 수 있다는 보고가 있어 ${ }^{16)}$ 감염 자체로도 면역 저하가 유발되었을 가능성이 있다.

본 증례의 환아는 초극소 저체중출생아로 태어난 미숙아로 쌍둥 이 둘째와 유사하게 출생 1 주일 이내에 기관지폐이형성증과 같은 임상 양상을 보여 이는 자궁 내 염증으로 인한 결과로 의심했다. 그 러나 환아의 경우 높은 수준의 인공호흡기 보조를 지속적으로 받게 되고 큰 호전이 없어 생후 39일부터 덱사메타손 치료를 시작했으나 결국 사망하였고, 사망 후 부검 결과에서 전신적인 거대세포바이러 스 감염이 확인되었다. 이에 본 증례를 통해서 오랜 기간 동안 높은 수준의 인공호흡기 치료가 필요하고 치료에도 반응이 없을 때 거대 세포바이러스 감염의 가능성을 함께 생각해봐야 한다는 것을 생각 해 볼 수 있다. 또한 미숙아에서 심각한 기관지폐이형성증의 치료로 덱사메타손을 반복적으로 투여하거나 고용량을 쓰게 되는 경우 투 약 전에 거대세포바이러스 감염 여부를 확인 후 투약하는 것도 고려 해야 한다.

\section{ARTICLE INFORMATION}

\section{Ethical statement}

This study was approved by the Seoul National University Hospital (IRB No.2002-065-1100). Informed consent was waived by the board.

\section{Conflicts of interest}

No potential conflict of interest relevant to this article was reported.

\section{Author contributions}

Conception or design: K.Y.K., E.K.K., Y.J.K., S.H.S., H.S.K.

Acquisition, analysis, or interpretation of data: K.Y.K., E.K.K., S.H.P., Y.J.K., S.H.S., H.S.K.

Drafting the work or revising: K.Y.K., E.K.K., S.H.P., Y.J.K.

Final approval of the manuscript: E.K.K., Y.J.K.

\section{ORCID}

Ka-Young Kim http://orcid.org/0000-0002-2037-4670

Ee-Kyung Kim http://orcid.org/0000-0002-7063-168X

\section{Acknowledgments}

None

\section{REFERENCES}

1. Bialas KM, Swamy GK, Permar SR. Perinatal cytomegalovirus in fections: epidemiology, prevention, and treatment. NeoReviews 2015;16:e231-5.

2. Choi SR, Kim KR, Kim DS, Kang JM, Kim SJ, Kim JM, etal. Changes in cytomegalovirus seroprevalence in Korea for 21 years: a single center study. Pediatr Infect Vaccine 2018;25:123-31.

3. Rawlinson WD, Boppana SB, Fowler KB, Kimberlin DW, Lazzarotto T, Alain S, et al. Congenital cytomegalovirus infection in pregnancy and the neonate: consensus recommendations for prevention, diagnosis, and therapy. Lancet Infect Dis 2017;17: e177-88.

4. Yasuda A, Kimura H, Hayakawa M, Ohshiro M, Kato Y, Matsuura $\mathrm{O}$, et al. Evaluation of cytomegalovirus infections transmitted via breast milk in preterm infants with a real-time polymerase chain reaction assay. Pediatrics 2003;111(6 Pt 1):1333-6.

5. Stehel EK, Sanchez PJ. Cytomegalovirus infection in the fetus and neonate. NeoReviews 2005;6:e38-45.

6. Coclite E, Di Natale C, Nigro G. Congenital and perinatal cyto- 
megalovirus lung infection. J Matern Fetal Neonatal Med 2013; 26:1671-5.

7. Hamprecht K, Goelz R. Postnatal cytomegalovirus infection through human milk in preterm infants: transmission, clinical presentation, and prevention. Clin Perinatol 2017;44:121-30.

8. Kelly MS, Benjamin DK, Puopolo KM, Laughon MM, Clark RH, Mukhopadhyay S, et al. Postnatal cytomegalovirus infection and the risk for bronchopulmonary dysplasia. JAMA Pediatr 2015;169:e153785.

9. Wesolowska A, Sinkiewicz-Darol E, Barbarska O, BernatowiczLojko U, Borszewska-Kornacka MK, van Goudoever JB. Innovative techniques of processing human milk to preserve key components. Nutrients 2019;11:1169.

10. Klotz D, Jansen S, Gebauer C, Fuchs H. Handling of breast milk by neonatal units: large differences in current practices and beliefs. Front Pediatr 2018;6:235.

11. Vamvakas EC. Is white blood cell reduction equivalent to antibody screening in preventing transmission of cytomegalovirus by transfusion?: a review of the literature and meta-analysis. Transfus Med Rev 2005;19:181-99.
12. Kim AR, Lee YK, Kim KA, Chu YK, Baik BY, Kim ES, et al. Transfusion-related cytomegalovirus infection among very low birth weight infants in an endemic area. J Korean Med Sci 2006;21:510.

13. Fischer C, Meylan P, Bickle Graz M, Gudinchet F, Vaudaux B, Berger $\mathrm{C}$, et al. Severe postnatally acquired cytomegalovirus infection presenting with colitis, pneumonitis and sepsis-like syndrome in an extremely low birthweight infant. Neonatology 2010;97:339-45.

14. Stoll BJ, Temprosa M, Tyson JE, Papile LA, Wright LL, Bauer CR, et al. Dexamethasone therapy increases infection in very low birth weight infants. Pediatrics 1999;104:e63.

15. Hussar P, Tokin I, Filimonova G, Hussar U. Dexamethasoneinduced T-lymphocyte apoptosis in different lymphoid organs. Pap Anthropol 2011;20:117-27.

16. Cicin-Sain L, Brien JD, Uhrlaub JL, Drabig A, Marandu TF, Nikolich-Zugich J. Cytomegalovirus infection impairs immune responses and accentuates T-cell pool changes observed in mice with aging. PLoS Pathog 2012;8:e1002849. 